\title{
THE COVID-19 PANDEMIC IMPACT ON CHILDREN'S EDUCATION IN Disadvantaged aNd RuRal AREA ACROSS INDONESIA
}

\author{
Mega Indrawati ${ }^{1}$, Cahyo Prihadi $^{2}$ and Ayu Siantoro ${ }^{3}$ \\ ${ }^{1}$ Education Unit, Wahana Visi Indonesia, Jakarta, Indonesia \\ ${ }^{2}$ Program Quality Assurance, Wahana Visi Indonesia, Jakarta, Indonesia \\ ${ }^{3}$ Ministry of Quality and Impact, Wahana Visi Indonesia, Jakarta, Indonesia
}

\begin{abstract}
This study used a mixed methods approach to capture key findings on COVID-19 impacts on education and challenges that hinder continued education particularly in disadvantaged and rural areas. The respondents were 900 parents, 943 children, 15 teachers and education officials in 594 villages in 9 provinces of Indonesia. The results showed that 1 out of 3 children stopped learning and children learned less. Children had limited access to widely supported online learning. While the offline method was more applicable, still it had some challenges. Children's mental health was affected and they experienced excessive emotions of fear and anxiety. Many parents were not ready to support children in learning school subjects while doing livelihood activities at the same time. Some children experienced domestic violence. Parents did not have a spare budget to provide distance learning facilities and had to sacrifice education over basic needs. The risk of drop out of school was heightened.
\end{abstract}

\section{KEYWORDS}

COVID-19, Education, Disadvantaged Area, Rural Area, Distance Learning, Mental Health

\section{INTRODUCTION}

The outbreak of pandemic due to COVID-19 since the beginning of 2020 in the world has had an impact on the multi-dimensional sector. In many households, immediate income loss indicates that the family was becoming unable to afford essential necessities, less inclined to access healthcare or education, and also at a greater risk of violence, exploitation, and abuse (UNICEF, 2020). The constrained activities of conventional teaching or face-to-face teaching forced Kemendikbud or the Ministry of Education and Culture (MoEC) Indonesia to take several policies, one of which is to promote distance learning. Teachers could continue to teach online using multiple platforms and students learn by being accompanied by a parent or caregiver at home. The impact of school closures was experienced by more than 68 million students and 4 million more teachers and educators (Kemendikbud, 2020).

School closures aggravated the already occurring inequalities. The most affected children were among those who have been vulnerable of being excluded from a quality education (Human Rights Watch, 2020). Schools especially in disadvantaged and rural areas experienced their own challenges due to limited access to technology to continue carrying out learning and teaching activities online, compared to schools in more developed areas. Household (HH) economy was impacted by the pandemic that might become a stressor both for parents and children that lead to violence, child labour, and school dropouts. Various limitations and challenges were faced by 
teachers and students to continue to be able to teach and study during distance learning, especially in disadvantaged and rural areas where the limited access to technology, infrastructures, and facilities was more profound than other more advanced areas.

There was lack of study on the effects of the COVID-19 pandemic on children's education in rural and disadvantaged areas across Indonesia that also correlated with other issues such as mental health, economic, health and nutrition, parenting, violence, child labour. This study aimed to answer the following research question: How is the COVID-19 pandemic impacts on children's education in disadvantaged and rural areas.

\section{LiTERATURE STUDY}

The impact of pandemic influenza was not just on human mortality and healthcare systems, but too on education and many livelihood sectors. Drake et.al mentioned that: "A pandemic event threatens all aspects of the economic and social fabric" (Drake et.al, 2012). The pandemic-related disturbance on education has already and will continue to substantially impact beyond education. Closures of schools during the pandemic impede the provision of basic services and necessities to children, because many parents are unable to work, and increase risks of violence (UNESCO, 2020). In education, COVID-19 pandemic could engender the quality education decline because distance learning requires new skills, both for students and teachers, especially for special education schools in front most, outermost and disadvantaged areas (Yarrow, 2020). Moreover, educational institutions closure also raised ethical and social issues, especially because they tend to disproportionately affect the underprivileged households (Cauchemez et al., 2009).

Closing schools carried consequential social, educational and economic disruptions that touch children across communities, but their impacts were especially serious for those who were already (UNESCO, 2020b). The pandemic forces the schools to close which led to the learning loss. The World Bank (2020) listed three conceivable scenarios for the loss of learning: a decrease in all students' average levels of learning, an enlarging distribution of learning performances due to profoundly unequal effects of the pandemic on different communities, or a significant rise of students with exceptionally low achievement, partially attributed to massive dropouts. As the loss of income cause parents to make tough decisions, education enrolment rates could decrease, particularly for girls, whereas child labour and abuse (UN, 2020). World Bank also predicted the increase in the number of people in extreme poverty due to COVID-19 by 71 to 100 million. Therefore, considerations should be paid to dropouts and opportunity costs that are likely to influence parent's choices to support their children's education (World Bank, 2020).

\section{STUdY MeTHOD}

A mixed-methods approach was used to describe the impacts of COVID-19 on education in disadvantaged and rural areas and highlight the key findings in this study. The study results would become a basis for recommendations toward a short-term rapid recovery and a comprehensive recovery in the long term. The combined approach of this study is selected as to provide in-depth understanding of the target audience, decision practices, and perceptions during pandemic. Quantitative and qualitative data collection was conducted in 35 districts, 247 subdistricts of 594 villages in 9 provinces namely North Sumatera, Bengkulu, Jakarta, East Java, Nusa Tenggara Timur, Central Sulawesi, North Maluku, West Kalimantan and Papua. The adult respondents as shown in Table 1 are $900 \mathrm{HH}$ (population 4.709) who can be men, women, grandparents or relatives (686 F, $214 \mathrm{M}$ ). Table 2 shows characteristic of child respondents. Children respondents are $943(353 \mathrm{~B}, 590 \mathrm{G})$ age 6 - below 18 years of age. Respondents are selected using non-probability sampling - convenience sampling and internet credit sampling. 
Each district was represented by $30 \mathrm{HH}$ that equally addressed 3 categories consisting of $\mathrm{HH}$ with children aged 0-5 years old, $\mathrm{HH}$ with children aged 6-11 years old, and $\mathrm{HH}$ with children aged 12-18 years old.

Table 1. Characteristic of household respondents

\begin{tabular}{|l|l|l|l|}
\hline Variables & Category & Amount & $\%$ \\
\hline Gender & Adult Men & 214 & 23.8 \\
\cline { 2 - 4 } & Adult Women & 686 & 76.2 \\
\hline \multirow{3}{*}{$\begin{array}{c}\text { Type of } \\
\text { community }\end{array}$} & Urban & 107 & 11.9 \\
\cline { 2 - 4 } Age group & Rural & 793 & 88.1 \\
\cline { 2 - 4 } & Below 25 years & 30 & 3.3 \\
\cline { 2 - 4 } & 25-44 years & 664 & 73.8 \\
\cline { 2 - 4 } & 45-59 years & 192 & 21.3 \\
\cline { 2 - 4 } & 60+ years & 14 & 1.6 \\
\hline Province & North Sumatera & 38 & $4,2 \%$ \\
\cline { 2 - 4 } & East Java & 35 & $3,9 \%$ \\
\cline { 2 - 4 } & DKI Jakarta & 34 & $3,8 \%$ \\
\cline { 2 - 4 } & Bengkulu & 33 & $3,7 \%$ \\
\cline { 2 - 4 } & Central Sulawesi & 96 & $10,7 \%$ \\
\cline { 2 - 4 } & Papua & 89 & $9,9 \%$ \\
\cline { 2 - 4 } & North Maluku & 79 & $8,8 \%$ \\
\cline { 2 - 4 } & West Kalimantan & 192 & $21,3 \%$ \\
\cline { 2 - 4 } & Nusa Tenggara Timur & 304 & $33,8 \%$ \\
\hline
\end{tabular}

Table 2. Characteristic of child respondents

\begin{tabular}{|l|l|l|l|}
\hline Variables & Category & Amount & $\%$ \\
\hline Gender & Boys & 353 & 37.4 \\
\hline & Girls & 590 & 62.6 \\
\hline Age group & 6-11 years & 301 & 31.9 \\
\hline & 12-18 years & 642 & 68.1 \\
\hline
\end{tabular}

Avoiding pandemic risks, the data collection was conducted under the COVID-19 safety protocol. Quantitative data was collected through a CATI survey combined with mobile data collection for $\mathrm{HH}$ and child respondents. Qualitative data was collected using Key Informant Interviews (KII) towards 15 community leaders, government representatives, teachers, and education officials across Indonesia, and desk reviews. The qualitative data analysis used is general inductive approach (Thomas, 2006). Data was aimed to capture issues of access, capacity, and $\mathrm{HH}$ economic conditions that contribute to child nutrition, ability to access education through the internet, mental health, violence and child labour. This study only captures the impact of COVID-19 without further analysis of intervention to address the issues. Locations were selected based on the areas where Wahana Visi Indonesia (WVI) operates in and/or reached by phone access, hence there are limitations in sampling representations. The number of respondents was limited because of access to the internet in rural areas. Thus the study was not intended to represent the whole population of Indonesia.

\section{RESUlt AND DisCUSSION}

\subsection{Children Received No Education}

The study found that some children were no longer schooling because they did not have distance learning access. As shown in Figure 1, only $68 \%$ of children had access to distance learning from 
home. In other words, 1 out of 3 children who did not get access to distance learning could not continue with their formal education. They could only wait for the schools to reopen to continue with their studies. This finding was aligned with a study on the impact of COVID-19 on children's education in Africa; that after schools closed amid the pandemic, many children received no education (HRW, 2020).

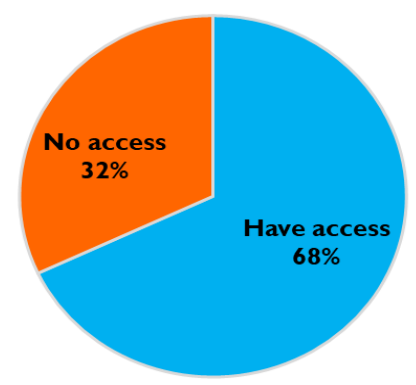

Figure 1. Proportion of children who have access to education

Many children received very little instruction, feedback, or interaction with their teachers. Some children were not taught at all during this period. In urban settings, distance learning is likely to be addressed by the local district education office, while in rural areas it was limited or unfocused. According to UNICEF (2020) findings, three-fourth students who could not be reached by distance learning live in rural areas and/or come from poor HHs. Moreover, $31 \%$ of schoolchildren globally could not be reached by digital and broadcast distance learning programs enacted to counter school closures. Regardless of the country's economic development, the vast larger part of students who cannot be reached by distance learning have almost always been from rural areas (UNICEF, 2020).

\subsection{Children Learn Less Through Distance Learning}

Students studied fewer topics or less content through distance learning. Furthermore, both technology-aided and home visit distance learning face challenges. Children were not ready to study independently through distance learning. Figure 2 shows children's challenges of learning from home. The finding indicated that $37 \%$ of children were not able to manage time to study, $30 \%$ had difficulties understanding the subject, $24 \%$ were not connected with internet access, $11 \%$ felt that there are too many tasks, and $21 \%$ did not understand the teacher's instruction and $6.5 \%$ did not have cell phone.

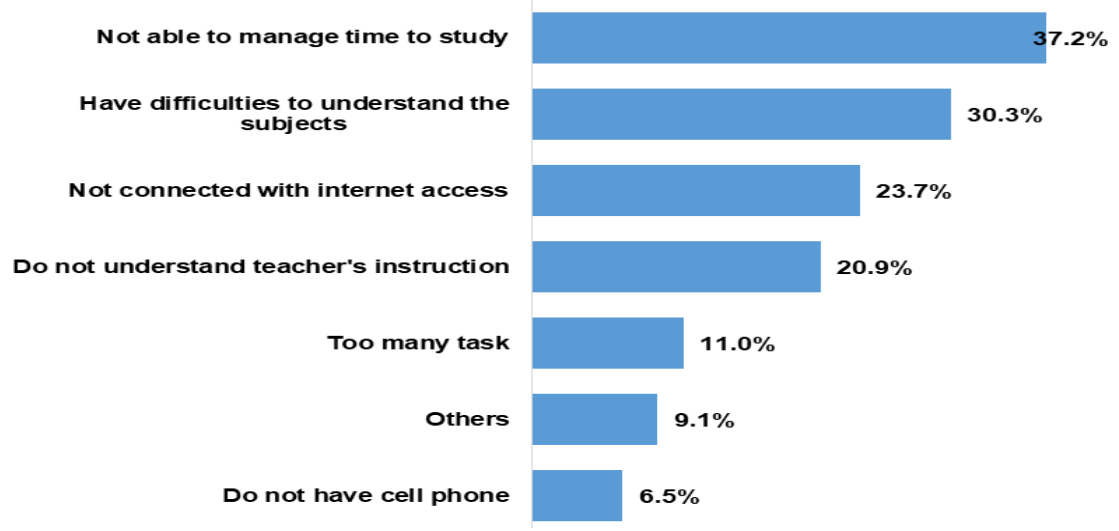

Figure 2. Children's challenges of learning from home 
Those findings are aligned with a statement from a village head who stated that: "... not all children can learn independently at home, most of them tend to play and have difficulty concentrating on learning." (Steven, the village head, Sentani - Papua). District Education Office (DEO) who claimed that: "Distance learning through the internet is not running well because the network is limited in mountainous areas like Jayawijaya. Teachers give text books, parents complain about too many tasks and independent learning given by teachers in text books, and children are confused to fill in the text books" (Bambang Budiandoyo, Head of Jayawijaya DEO, Papua Province). Moreover, teachers and schools also did not have sufficient capacities in applying computer skills to teach.

Digital literacy - for students and teachers - is increasingly acknowledged as a vital element of children's right to education. Although some students had received paper assignments, they were still far away from getting a quality education, at least from what they had had before the pandemic. Many students in developing countries, particularly young children and ethnic minority, are not fluent in the language of instruction at school. Even if students could access educational materials they could comprehend, many did not benefit from the supported learning methods during the pandemic due to bad living conditions, economic stress, as well as having parents with low education levels and digital skills (UNESCO, 2020). For instance, in most European countries, lower socio-economic backgrounds children tend to lack opportunity to read, a quiet room to study, and parental support amid school closure. Similarly, UNICEF found that in both low income and upper-middle income countries, children in the most indigent households got significantly less help with their homework (UNICEF, 2020). The short- and long-term learning loss was expected to be tremendous. Researchers in Canada estimate that the pandemic could widen the socio-economic skills gap by more than $30 \%$ (Haeck and Lefebvre, 2020).

\subsection{Children Have Limited Access to Technologies}

Lack of supporting facilities was the reason why children are unable to access distance learning. Limited access to radio, television, and computer, mobile devices such as mobile phone and tablet, and internet connection left many students unable to engage in online distance learning. In disadvantaged and rural areas, problems in the availability of electricity, internet connection, and radio transmission were still detrimental. Therefore, distance learning did not cover all students equally. Differences in each area's technology accessibility resulted in educational inequality. The European Commission (2020) also found accordingly, that the most vulnerable learners were among those who lack digital competencies and access to the computers/gadgets and connectivity needed for distance learning methods utilized during the school closure. In half of 21 European countries assessed, primary school students from lower socio-economic families only had half of the internet access their more privileged peers had (European Commission, 2020).

Children's access to education is shown in Figure 3. For children who have access to online learning systems, most (20\%) of them used WhatsApp to communicate with teachers, and $10 \%$ utilized more interactive applications such as Zoom, Skype, and Google Meet. Moreover, there were also some children using more conventional media such as attending the learning programs initiated by the Ministry of Education and Culture through television. Media used for learning from home activities varied from using digital technology. 
International Journal of Education (IJE) Vol.8, No.4, December 2020

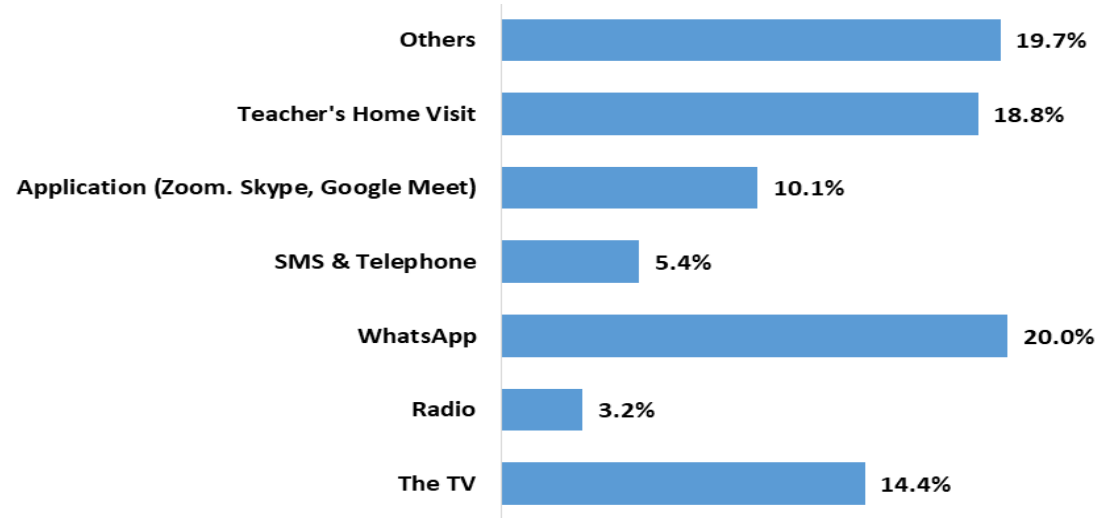

Figure 3. Children's access to education

Offline distance learning methods such as teacher home visits (19\%) and using printed materials were more applicable in this case. Some children attended the teacher home visit method or the teacher visits the student at home. Both online and offline methods had their challenges, such as teacher home visit method exposed children and teacher to a higher risk of contracting COVID19 and the lack of guidelines or protocols for carrying out distance learning. The capacity of teachers and schools was very limited, so they were not ready to implement distance learning. Students who had access to online distance learning system, they were hindered by the unaffordable cost of the internet or the lack of gadget in the family. Children had to take turns using devices if there were more than one school-aged child in the family. As a teacher claimed that: "At the school where I work, there are arrangements for teachers... Every Monday and Tuesday, students will come to the teacher's house to study and the rest of the week they will study at home. The number of students in a group is limited to 10 children who live in adjacent areas. The challenge is that it is difficult for teachers to teach because this group comes from different grades... facilities are limited as well, there is no whiteboard available" (Marselinus, a primary school teacher in East Manggarai Regency, East Nusa Tenggara Province).

MoEC had organized television shows for distance learning and local governments had arranged school courses through radio. Nonetheless, not all children could participate because of the absence of electricity, TV or radio signal, or the TV or radio device itself. Furthermore, while the role of internet connection in education during the pandemic was progressively becoming indispensable, many children lack access to it. Some children lived in areas with poor or no internet connection, while others had no access to internet-enabling smartphones. Digital distance learning was not an option for those children. Onyema et.al, (2020) found similar finding that lacking infrastructures (e.g. network, power, or other inaccessibility and unavailability issues) and poor digital competencies had constrained the success of online education.

The types of support expected for schooling at home as shown in Figure 4, indicated that $63 \%$ children needed textbooks, $28 \%$ need storybooks with pictures, $23 \%$ needed internet credit, and $17 \%$ needed stationery to make artwork. 


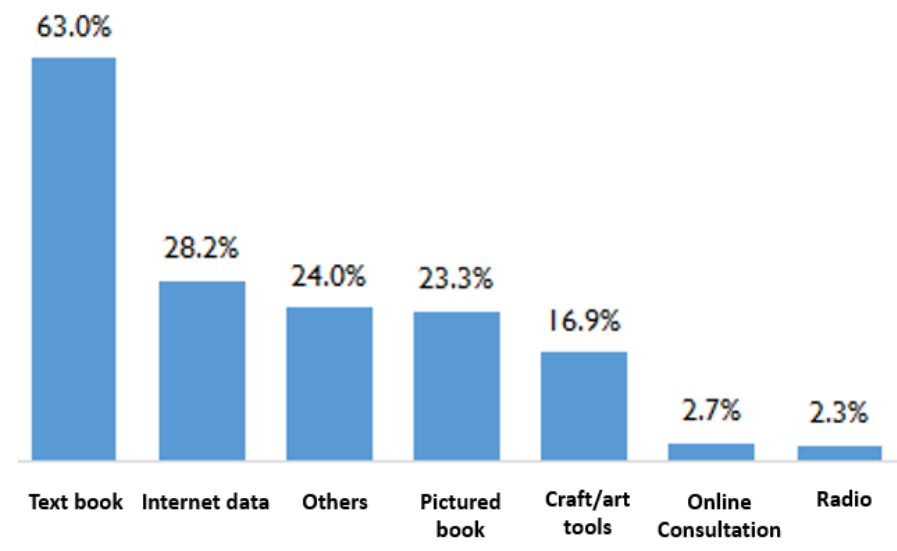

Figure 4. The support that children need for distance learning

Papua province, one of the most underdeveloped area in Indonesia, had a lower rate of online distance learning, as claimed by the education official: "Approximately only $34 \%$ children can learn through the internet, and $66 \%$ children have to learn without internet in distance learning in Papua" (Christian Sohilait, Head of Papua Province Education Office-PEO).

\subsection{Children's Mental Health Affected}

The pandemic affected the psychological and social conditions of children. The study reported that $57.6 \%$ of the children felt isolated (confined) or stressed out (depressed, anxious, worried, scared) because of COVID-19. They experienced excessive emotions of fear and anxiety towards the current situation, the boredom of staying at home due to the inability to play freely or meet physically with their peers, as well as the inability to do their hobbies and extracurricular or recreational outdoors activities. Children were asked whether they enjoyed learning from home and $42.6 \%$ of the children did not enjoy learning from home at all. They preferred to study at school because they were tired of studying at home without interaction with their friends. A principal stated that: "At first, the children were happy with distance learning, at 8 am they contacted their teacher to ask for assignments to do. But now they are tired and bored, they miss school and their friends" (Anis, Simokerto District - East Java).

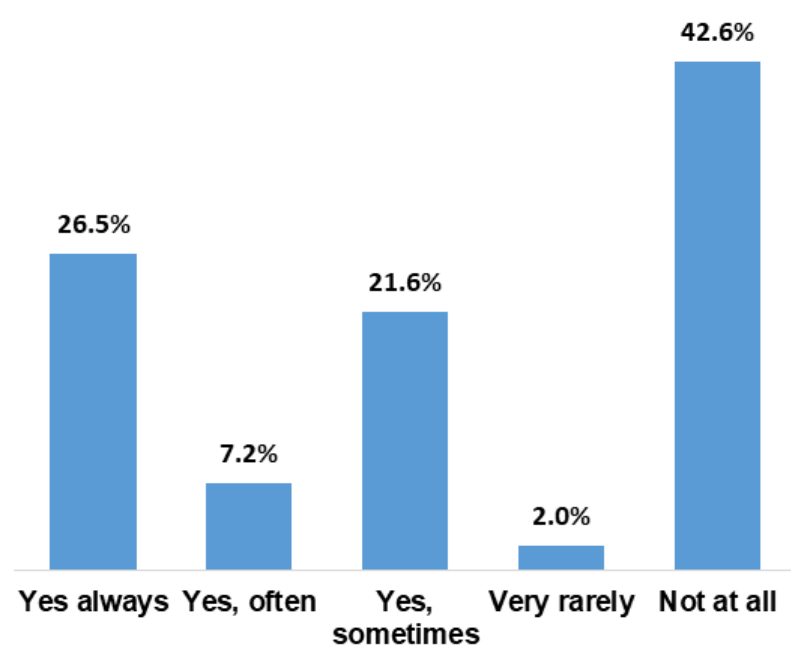

Figure 5. Frequency of children enjoy learning from home 
The pandemic and school closures brrought stress to children's mental health. They attributed negative affect such as anxiety, isolation, stress, and depression to reduced interaction with their peers at school (HRW, 2020). As shown in Figure 6, the study found that $48.7 \%$ of children felt bored studying at home with no interactions with their friends. Nevertheless, $20.8 \%$ of children were afraid of losing contact with their friends. $33.7 \%$ of children worried about getting sick and $14.3 \%$ of them also felt unsafe due to COVID-19. $20.8 \%$ of children. Stress related to academic achievement and economics were also found as $34.9 \%$ of children were worried about missing school lessons and $9.4 \%$ of them were worried about parental income and lack of food.

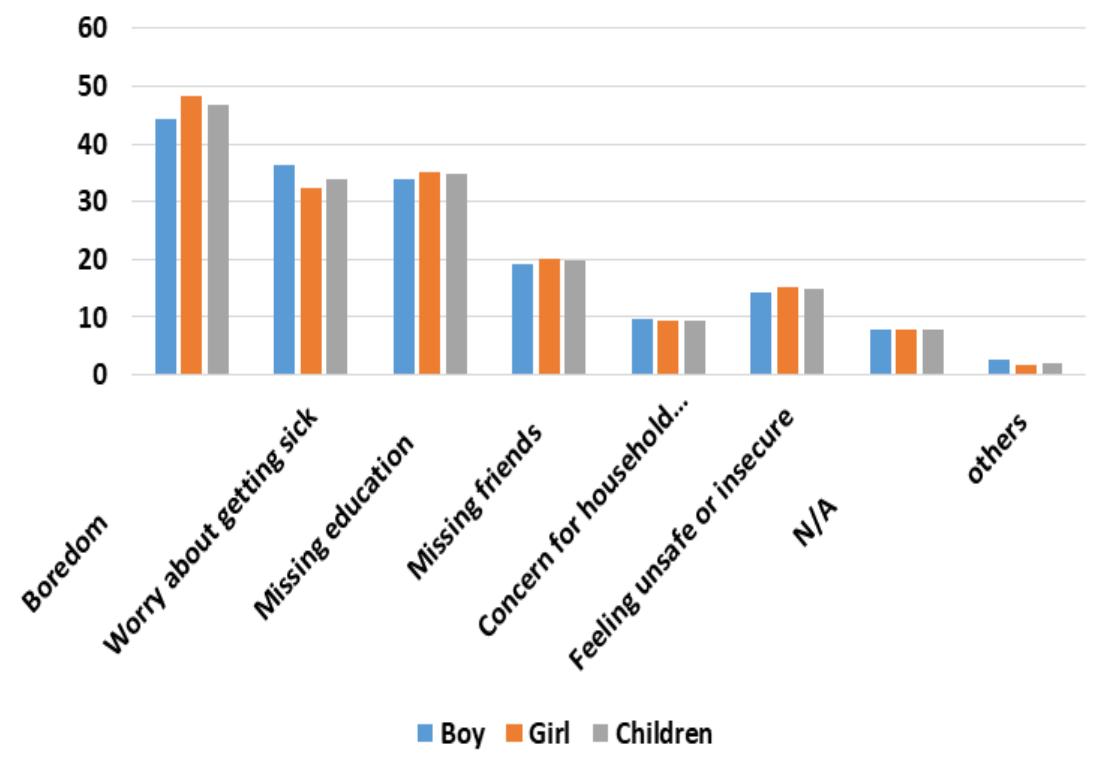

Figure 6. Level of children's psychosocial stressor

This finding is in line with a study by Cao et al., (2020) which investigated the effect of COVID19 pandemic on education and well-being of students. Approximately $25 \%$ of the study participants reported experiencing anxiety symptoms that were positively correlated with concerns about the impact of the pandemic on academic delays, as well as economic and daily life disruption (Cao et al., 2020). Those stressors would have a negative impact if their severity was above the children tolerance threshold and continuously occurred without appropriate mitigation. In line with WVI's findings in the field, the National PKTA Alliance (Elimination of Violence Againts Children Alliance) survey also found that learning from home had social and emotional impacts on children. As many as $40 \%$ of students felt exhausted of studying at home and $10 \%$ were unhappy with the learning process at home (PKPA \& Aliansi PKTA, 2020).

Stressors also came from parents who worried about the risk of getting the disease and could not afford the hospital bills because they did not have medical insurance. Only 50\% of $\mathrm{HH}$ had medical insurance for all the family members, $30 \%$ had medical insurance for some of the family members, and 29\% HH did not have medical insurance at all. Teachers also faced challenges such as economic issue that drive them to have mental health consequences. As learning from home directly resulted in lower salaries for some teachers, teachers' economic challenges also became stressors that affect learning process. This issue was also mentioned by an education official who stated that: "In general, honorary teachers who were paid based on teaching hours in private schools experienced reduced or lost earnings. Because there is no face-to-face learning activity in schools during the pandemic, meaning that the committee teachers do not earn salaries as before in Nusa Tenggara Timur Province" (Head of Nusa Tenggara Timur PEO). 


\subsection{Parenting and Domestic Violence Against Children}

The suspended in-person formal education activities forced children to stay and study at home. Handling the situation at home was crucial for parents or caregivers whilst the stresses of socialeconomic impact were emerging. As shown in Figure 7, this study found that $62 \% \mathrm{HH}$ said they could handle the situation in full control, while $28.7 \% \mathrm{HH}$ could only handle partially. Female caregivers showed better capacity in handling the situation using positive parenting (64\%) compared to male caregivers (55\%).

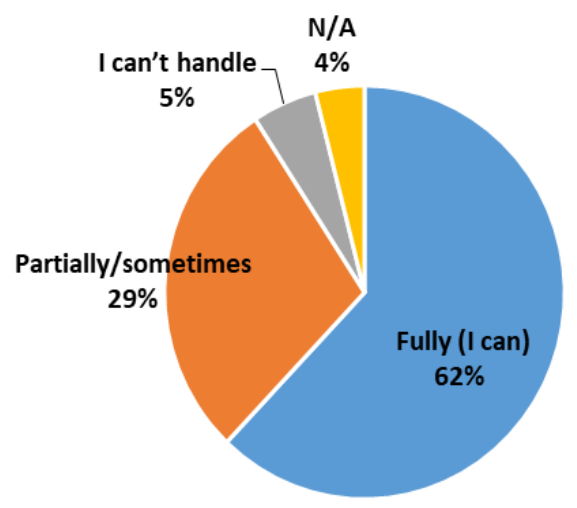

Figure 7. Parents can handle situation at home during distance learning

Parents were also asked their decision of child care mitigation if they were contracted with COVID-19. As shown in Figure 8 as much as 55\% of parents stated that they will leave their children to their extended families, $25 \%$ to their spouse, $3 \%$ to their neighbours, and $13 \%$ of parents did not know who to leave their children to. This issue should be further discussed internally in the family to have their support system to anticipate if the case occurs.

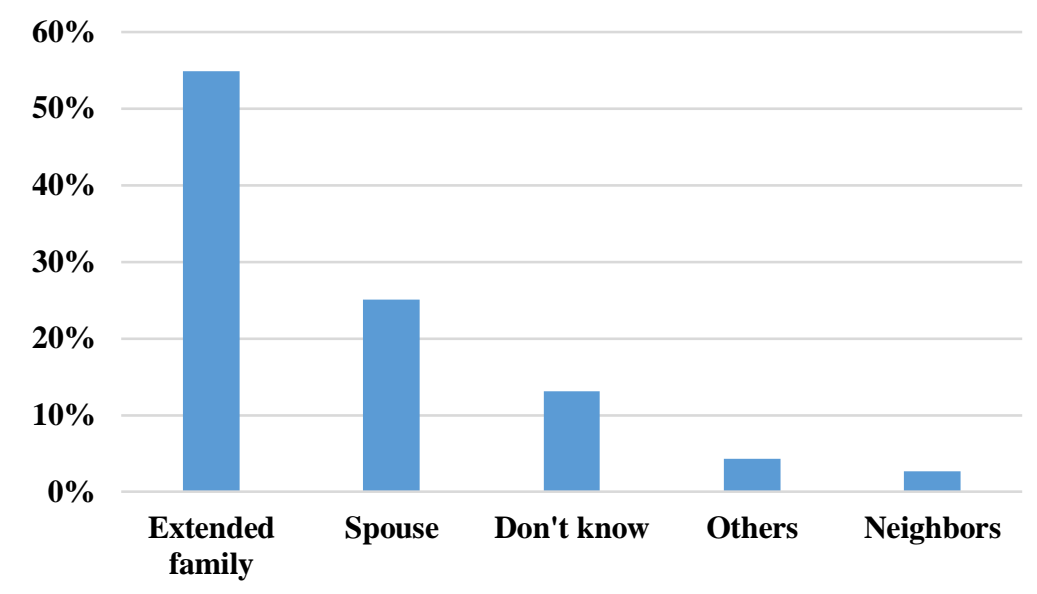

Figure 8. Parenting conducted a month before survey

Some children experienced violence at home. Kind of parenting applied at home a month before survey is shown in Figure 9; with 33.8\% children experienced yelling-shouting and $11.3 \%$ experienced physical punishment. Distance learning were more likely to let children learned on their own without supervision. This raised another issue especially for children with internet access as they became more vulnerable to exposure to pornographic or other negative content. 
International Journal of Education (IJE) Vol.8, No.4, December 2020

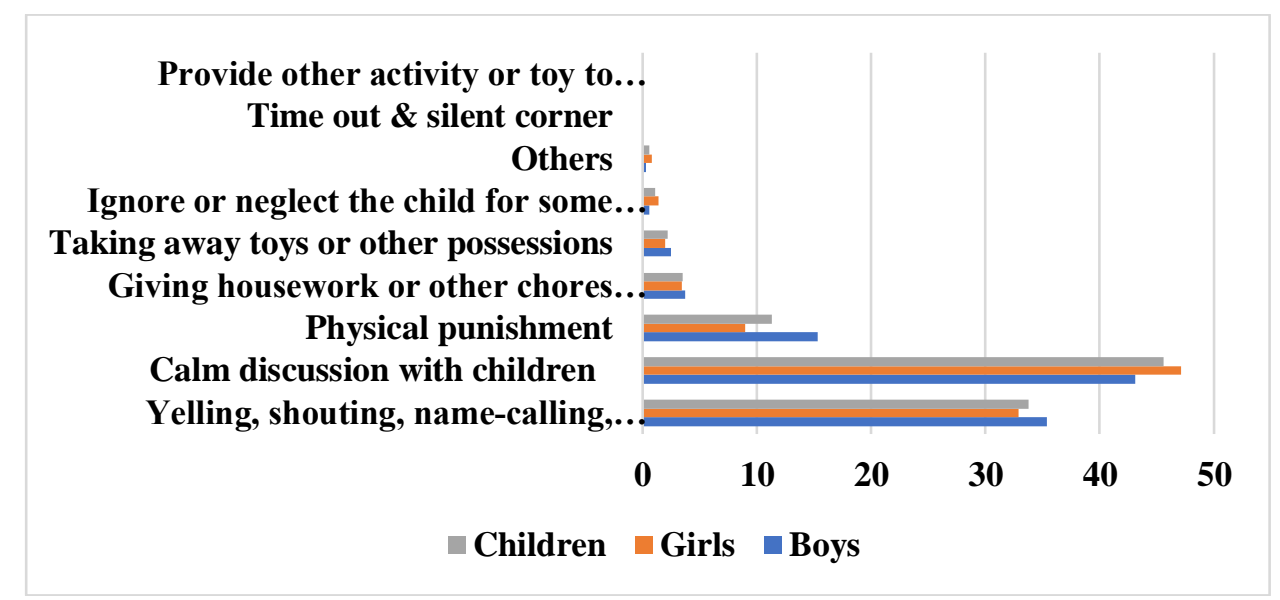

Figure 9. Parenting during the pandemic

The survey also revealed only $34 \%$ of parents regularly monitored their children when using gadgets and accessing the internet. Nevertheless, parents and caregivers were not ready to replace the responsibilities as a teacher or to support children in learning the school subjects while doing livelihood activities at the same time. Caregivers with little or no formal education had greater difficulty supporting children with learning from home. A spiritual leader clarified that: "For the time being, there is no support from schools to parents ... it seems that schools only give assignments to children (with a little instruction), it is very difficult for parents to facilitate children to learn at home because they may not understand the subjects and most parents tend to let their children study alone." (Pastor Navy Kastanya, Sentani District).

\subsection{Children Live in Poverty}

The pandemic exacerbated the already dire living conditions for many families. COVID-19 pandemic had decreased the income of almost 9 out of $10 \mathrm{HH}$ respondents. $\mathrm{HH}$ expenditures before and after the pandemic also showed a decreasing trend from $\$ 24.9$ per week to $\$ 18.9$. Learning can take place well where basic needs including physical needs such as food and nutrition, water sanitation, and hygiene (WASH) were fulfilled first. Oftentimes, some $\mathrm{HH}$ had to sacrifice education over basic needs. Some parents did not have a spare budget to provide distance learning facilities (e.g. radio, TV, smartphone, internet credit). As shown in Figure 10, this study found that education was the third most critical issue (38\%) faced by $\mathrm{HH}$ during the pandemic, after livelihoods (80\%) and food (49\%).

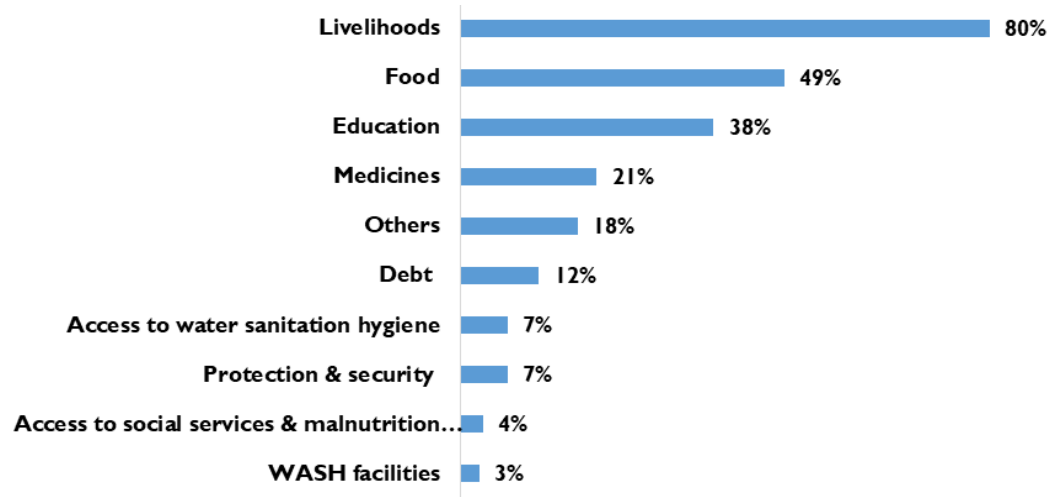

Figure 10. Respondent's priority during pandemic 
It was reported that $53 \%$ of $\mathrm{HH}$ respondents were not able to provide nutritious food (4 sources of nutrition for balanced diet). Food security was also at risk, with $47.5 \%$ of $\mathrm{HH}$ having food supply for less than 2 weeks, while only $20.4 \%$ of $\mathrm{HH}$ had food stock for more than a month. Regarding daily proper meals, $20.9 \%$ of children had 2 or fewer meals per day and only $74 \%$ of children could eat 3 meals per day. Low consumption with low variety and frequency of food for the vulnerable groups led to low energy and concentration during learning activities, acute malnutrition in the short period of time, and chronic malnutrition in the long run.

Meanwhile, some of the WASH needs were not fulfilled. As much as $31 \% \mathrm{HH}$ did not have sufficient WASH access for livelihood activities, 10\% for toileting, 10\% for hand washing, 10\% for house cleaning, $6 \%$ for showering, $4 \%$ for drinking and cooking. There was $9 \%$ of $\mathrm{HH}$ who did not have access to hygiene facilities (e.g. private or public toilets) and $7.3 \%$ had no access to hygiene supplies because they could not afford it. Thrifting was the strategy the majority of $\mathrm{HH}$ took as a coping mechanism during the times when less income was generated but routine basic needs must be addressed. Only $23 \%$ of $\mathrm{HH}$ had sufficient savings. For $79.2 \%$ of $\mathrm{HH}$, their savings were only enough for less than a month. In this situation, fragile $\mathrm{HH}$ had to prioritize some needs over others. A student stated that: "I want the regent/mayor/governor to respond quickly to the outbreak. And to free the internet credit, because at this time, it is difficult to earn money to buy internet credit. Meanwhile, the online tasks of teachers are always increasing." (A student, 17 years old, Sambas District, West Borneo Province). This finding was in line with UNICEF's survey in Indonesia that explained rapid impoverishment of families with children would make healthy food less accessible, available, and affordable, which eventually devastate the $\mathrm{HH}$ food security. Due to financial constraints, $36 \%$ of respondents frequently ate less than they normally should - a sign of increasing food insecurity. Reduced HH income also caused a high risk for a surge in wasting and micronutrient deficiencies among children (UNICEF, 2020).

\subsection{Children Who Work and Child Labour}

The risk of children dropping out of school was heightened during the pandemic. UNESCO (2020) predicted that because of the economic effects of the pandemic alone, 23.8 million additional children and teenagers may stop going to school in 2021. The currently out-of-school children due to the pandemic had begun helping their parents work in the paddy field, or hunting and gathering in the forest.

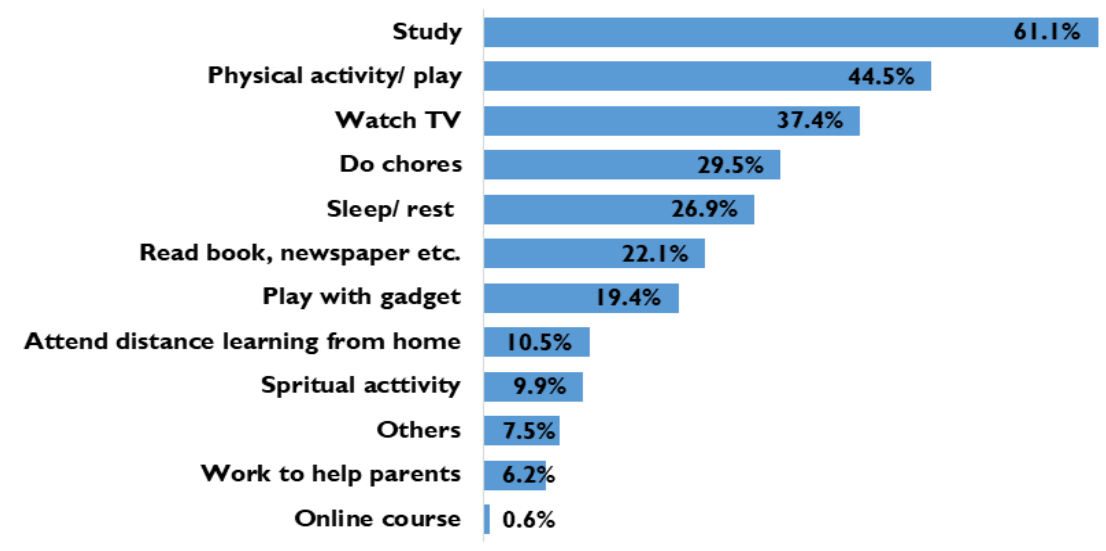

Figure 11. Children's daily routine during the pandemic

As shown in Figure 11 about children's daily routine during the pandemic, $6.2 \%$ of children had to work to help their parents and $29.5 \%$ children do household chores. This study also reported 
from parents' answers that $3.6 \%$ of parents had been sending children to work. Girls were frequently expected to do domestic works, such as tending the house or caring for their young siblings (HRW, 2020). Their chores had increased because schools had been closed. They might sometimes miss distance learning classes because of their chores at home. Children in rural areas, whose parents had low education (elementary/junior high school graduates) and needed help for economic continuation (e.g. harvesting yields) often chose helping parents to work rather than learning from home. Working to help parents were more likely to be found in children whose parents only work in the informal sector and rely on daily income. Such parents also had difficulties in meeting their daily needs and had the potential to send children to work (selling, working in fields, etc.). A child stated that: "The schools are still closed. So many parents prefer their children working in the farms ... so children who are supposed to stay at home and comply with the PSBB (large-scaled social restriction] are now wandering around in the farm" (MI, 13 years old, Ende District - Nusa Tenggara Timur Province). This situation also mentioned by the DEO of Ngada District who stated that: "One of the obstacles in Ngada District is that parents still consider the child as labour so when the teachers do home visit they then have to chase the child and study in the paddy field." (Vinsensius Milo, Head of Ngada District Education Office, Nusa Tenggara Timur Province). In their most recent data, ILO (2020) recorded that among 152 million of child labour worldwide, the majority of them work in the agriculture sector. This is in line with child labours in Indonesia, which most of them were employed in the agriculture and forestry child labourers (ILO, 2020). The head of the Child Forum of Jokarto Village in East Java said that during the pandemic, more children preferred to work and help their families due to lack of technology, lack of teachers and ease of the family's economic burdens. "...children should not work, they should go to school".

\section{CONClusion}

The COVID-19 pandemic had affected children's education directly and indirectly. The change into distance learning suddenly had brought more challenges in disadvantaged and rural areas since they have less infrastructure, access, skill to utilize technology, limited guidance from parents and teachers. One third of children did not even have any access to education. Children learned less as they were not ready to learn independently through distance learning. Teacher home visits worked best for children in rural areas but they still needed reading books and printed materials. Indirect impact had taken in children living in poverty where some parents had to sacrifice education over basic needs. Some parents did not have a spare budget to provide distance learning facilities such as buying devices and internet credit. Mental health was also impacted because children experienced excessive emotions of fear and anxiety towards the current situation, boredom of being kept at home and not being able to play freely or meet physically with peers, and not being able to do hobbies, extracurricular or other recreational activities outdoors, fear of family's well-being. One fourth of parents could not fully control the situation at home. Violence both verbally and physically still occurred at home. The risk of children dropping out of school was heightened during the pandemic because the children had begun helping their parents to work.

\section{RECOMMENDATION}

Access to the internet and digital literacy are becoming more and more essential for children in their pursuit of their right to education. Government of Indonesia should accelerate the infrastructure including electricity and internet in disadvantaged and rural areas so that children can access online distance learning. They ought to take all conceivable measures to make dependable and affordable internet service benefit all students (HRW, 2020). The government should also take steps to alleviate disproportionate difficulties for impoverished and underserved 
populations, including discovering approaches to provide discounted or free access to data, services, and computers.

Provincial and DEO should provide access to education based on the context and need of each area. In some areas, where teacher visits work better than other options but facing challenges in transportation or gasoline fees, transportation support should be given. Therefore, teachers using home visit methods can be supported with transportation stipends because they have to go deep in the villages. Meanwhile, WVI has a cash transfer assistance program for honorary teachers in East Manggarai and \& West Manggarai Districts. The program is divided into two types which are Cash for Training (CFT) and Cash for Work (CFW). CFT program is aimed to increase the capacity of teachers to do distance learning, such as to increase knowledge about COVID-19, socialization of learning from home regulation of MoEC on simplifying learning material, while CFW is dedicated to honorary teachers who are economically impacted in this pandemic. In CFT programs, teachers who have been trained then utilize the skill and they are monitored by sending photos or videos and lesson plans to the supervisor. Teachers who meet all the requirements will then get the cash transferred into their bank account. This innovation is highly appreciated by both the DEO and the PEO of Nusa Tenggara Timur. The program not only supports the basic needs of teachers but also improves the quality and capacity of teachers to teach in pandemic situations. This good practice might be replicated by DEO in other schools. The regulation that enables school operational funding used for internet credit for students and teachers, might better be allocated for teacher home visits in rural areas where internet is not available or cell phone ownership is scarce.

In some areas where access to technology is limited, children need more materials to learn conventionally. They should be provided with printed reading materials that are relevant to the simplified focus of learning during pandemic, that are literacy and life skills -health and COVID19 spread mitigation. WVI has distributed reading books that aimed to support literacy and health for children in 18 districts in rural parts of Indonesia. To meet with the local context, WVI also contextualized contents for local stories book and pocket book of COVID-19 for Papuan children, then the DEO printed and distributed those books across Papua. Local governments in other rural areas might consider this practice. Learning through radio that may work in rural areas with radio transmission signals has been done in West Borneo and Papua. WVI distributed radio units to children and worked with local radio stations and DEO in 3 districts -that represent different geographic areas mountain, lake and coastal- to conduct learning through radio programs. Teachers act as the radio announcers. Radio program is not only used for learning purposes but also for psychosocial support through songs, stories, quizzes and sharing sessions. Oftentimes, teenage students lead peer learning for English subject. Radio programs might also be used to educate society, like parenting and health education for parents. Learning activity that may work in some rural areas is village study groups outdoor (if weather permits) where students sit in socially distanced same grade groups to do exercises or exam practices with help of high school graduates or visiting teachers for a couple hours, two or three times a week. Particularly for students whose key exams are approaching, their high motivation to study might help this method to work Mental health support for children, parents and teachers should be provided throughout the pandemic. Capacity building and parental engagement related to the role of parents in learning at home, non-violent positive parenting, and raising awareness of child rights on education should be planned. Provincial or DEO should have a program to prepare teachers' and parents' psychological conditions to be able to give psychosocial support for children; which might collaborate with NGOs and teachers' association. WVI in collaboration with Directorate General of Teachers and Education Officials of MoEC have developed psychosocial in pandemic pocket book for teachers and parents, which might be used for teacher and parents on psychosocial trainings. Training on psychosocial and child development as a precondition of 
teaching and fostering the mental and character of students should take place before schools reopen. Ensuring access to psychosocial support services for school members is necessary so they can overcome the anxiety and hesitation about returning to school. Schoolchildren from poor family should be given some basic necessity aids, such as nutritious food stock and personal hygiene kit, to minimize the risk of malnutrition and diseases. District Social Office should monitor the poor schoolchildren welfare and promote the local governmental aid by reallocating some of operational funding of local government at the provincial or district level.

Local governments should plan to promptly get children back to school once Covid-19 is under control in their area (HRW, 2020). In line with MoEC guidelines, cooperation with relevant institutions, such as Health District Office, to plan a public health strategy in avoiding and controlling the spread of Covid-19 is necessary. Local government should also devise educational strategies to provide remedial schooling for children who were unable to adopt distance learning and for children who were out of school due to other causes prior to the pandemic. Teachers who implemented distance learning should track which students participate, reach out to those not participating, and try to help them re-engage. All measures taken by government and nongovernmental organizations to reassure children returning to the reopened schools should be inclusive and focused on the most vulnerable or marginalized children (UNESCO,2020): including children with disabilities, children living in poverty, children who work, children in disadvantaged and rural areas, paying particular attention to girls within these groups. These children are the one who have more potential not getting quality education through distance learning during the pandemic.

\section{ACKNOWLEDGEMENTS}

The authors would like to thank:

- Dr. Drs. Rachmadi Widdiharto, M.A. as the Director of Teacher and Education Officials of Primary Education - Ministry of Education and Culture of the Republic of Indonesia (Direktur Guru dan Tenaga Kependidikan Pendidikan Dasar - Kementerian Pendidikan dan Kebudayaan Republik Indonesia)

- Mitra Tobing S.T. as the Director of Ministry of Quality and Impact of WVI

- The Program Quality Assurance unit of WVI

- World Vision International

\section{REFERENCES}

[1] Cao, W., Fang,Z., Hou, G., Han, M., Xu., Dong, J., Zheng, J. (2020) "The psychological impact of the COVID-19 epidemic on college students in China", Psychiatry Research, 287, Article 112984. https://doi.org/10.1016/j.psychres.2020.112934.

[2] Cauchemez, S., Ferguson, N. M., Wachtel, C., Tegnell, A., Saour, G., Duncan, B., \& Nicoll, A. (2009) "Closure of schools during an influenza pandemic. The Lancet infectious diseases", 9(8), pp473-481.

[3] Drake, T. L., Chalabi, Z., \& Coker, R. (2012) Cost-effectiveness analysis of pandemic influenza preparedness: what's missing? Bull world health Organ, 90 (12), 940-941. DOI: 10.2471/BLT.12.109025

[4] European Commission, "Educational inequalities in Europe and physical school closures during Covid-19", Retrieved from https://ec.europa. eu/jrc/sites/jrcsh/files/fairness_pb2020_wave04_covid_education_jrc_i1_19jun2020.pdf.

[5] Haeck, C., Lefebvre, P. (2020) Program for international student assessment (PISA), "Pandemic school closures may increase inequality in test scores", Working Paper No. 20-03, June 2020, 
International Journal of Education (IJE) Vol.8, No.4, December 2020

Retrieved from https:/grch.esg.uqam.ca/wp-content/uploads/sites/82/

Haeck_Lefebvre_GRCH_WP20-03-5.pdf.

[6] Hanna and Olken, (2020), 'Current Results of Online Survey' in Children in Indonesia An Agenda for action to address socio-economic challenges, UNICEF, Jakarta, 11 May 2020

[7] Human Rights Watch (2020). Impact of Covid-19 on Children's Education in Africa. Submission to the African Committee of Experts on the Rights and Welfare of the Child, 35th Ordinary Session. Human Rights Watch: Observer status $\mathrm{N}^{0}$. 025/2017 Retrieved from https://www.hrw.org/sites/default/files/media_2020/08/Discussion\%20Paper\%20-

$\% 20$ Covid\%20for\%20ACERWC.pdf

[8] ILO (2020). COVID-19 and child labour: Combating increased exploitation of children during the COVID-19 pandemic. Retrieved on 03 August 2020 from https://www.ilo.org/jakarta/info/public/pr/WCMS_752406/lang--en/index.htm

[9] Kemendikbud. (2020). Surat Edaran Menteri Pendidikan Nomor 4 Tahun 2020 Tentang Pelaksanaan Pelaksanaan Kebijakan Pendidikan Dalam Masa Darurat Penyebaran COVID-19. Jakarta: Kemendikbud.

[10] Noah Yarrow, E. M. (2020). Estimated impacts of COVID-19 on learning and earning in Indonesia: How to Turn the Tide. Jakarta: World Bank Indonesia.

[11] Onyema, E.M., Eucheria, N.C., Obafemi, F.A., Sen, S., Atonye, F.G., (2020) "Impact of coronavirus pandemic on education", Journal of Education and Practice, Vol. 11, No. 13. DOI: 10.7176/JEP/1113-12.

[12] Pusat Kajian Dan Perlindungan Anak dan Aliansi PKTA (2020). Pandangan Anak Terhadap Covid19 di Indonesia. Jakarta: PKPA \& Aliansi PKTA.

[13] Thomas, David, (2006). "A general inductive approach for analyzing qualitative evaluation data", American Journal of Evaluation, Vol. 27, pp237-246.

[14] UNESCO (2020). 290 Million students stay home due to Coronavirus. Retrieved from https://en.unesco.org/news/290-million-students-out-school-due-covid-19-unesco-releases-firstglobal-numbers-and-mobilizes

[15] UNESCO, GEM Report, 2020.

[16] UNICEF (2020). COVID-19 and children: An agenda for action to address socio-economic challenges 11 May 2020 Retrieved from https://data.unicef.org/topic/covid-19-and-children/ https://www.unicef.org/indonesia/sites/unicef.org.indonesia/files/2020-05/COVID-19-and-Childrenin-Indonesia-2020_0.pdf

[17] UNICEF (2020). COVD-19: Are children able to continue learning during school closures? A global analysis of the potential reach of rural learning policies. Retrieved in August from https://data.unicef.org/resources/remote-learning-reachability-factsheet/

[18] UNICEF, "How involved are parents in their children's learning? MICS6 data reveal critical insights", available at https://blogs.unicef.org/ evidence-for-action/parental-involvement-childrenslearning

[19] United Nation (2020). Policy brief: Education during COVID-19 and beyond. Retrieved from https://www.un.org/development/desa/dspd/wp-

content/uploads/sites/22/2020/08/sg_policy_brief_covid-19_and_education_august_2020.pdf

[20] World Bank (2020) "We should avoid flattening the curve in education - Possible scenarios for learning loss during the school lockdowns", 13 April 2020. Retrieved from https://blogs.worldbank.org/education/we-should-avoid-flattening-curve-education-possiblescenarios-learning-loss-during-school

[21] World Bank (2020). "Projected poverty impacts of COVID-19", Retrieved from https://www.worldbank.org/en/topic/poverty/brief/projected-poverty-impacts-of-COVID-19

\section{AUTHORS}

Mega Indrawati is education team leader at Wahana Visi Indonesia with 5 years' experience in education in development includes programs for basic education, early childhood education, teacher professional development and education in emergency. She holds a Master's degree in Education Management and Early Childhood Education from Jakarta State University. Her current research includes education continuation in pandemic.

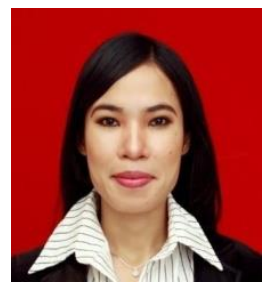


International Journal of Education (IJE) Vol.8, No.4, December 2020

Cahyo Prihadi is Program Quality and Accountability Manager at Wahana Visi Indonesia with 15 years of wide experience of design, monitoring, and evaluation of multi sectoral programming including basic education and early childhood education. He holds a Master's degree in Social Welfare of University of Indonesia. His current research is related to social accountability for health in leveraging public policies and programs.

Ayu Siantoro is Program Research and Innovation Specialist at Wahana Visi Indonesia (WVI). She graduated from Faculty of Psychology University of Indonesia and holds a Master's degree in Social Cognition: Research and Applications from Faculty of Brain Science, University College London. Prior to WVI, Ayu worked at the Coordinating Ministry of Human Development \& Cultural Affairs, the Executive Office of the President of the Republic of Indonesia, and Kompas Daily Newspaper.
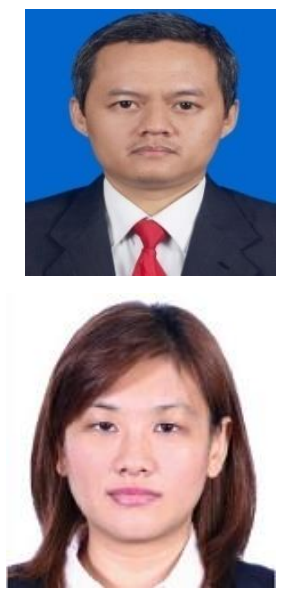